cribed during he finishing period. The supply of horse-beans at a mean rate (4o to 50 p. Ioo of the complementary proteins) has to be decided by taking into account the price differences compared to other protein sources and the forecasted reduction of animal performances.

\title{
SUBSTITUTION TOTALE OU PARTIELLE DU TOURTEAU DE SOJA CUIT DANS DES RATIONS A BASE DE MAÏS
}

\author{
J. CASTAING et J. MOAL \\ Association générale des Producteurs de Mais \\ 64000 Pau \\ RÉSUMÉ \\ $7^{\text {er Expérience }}$
}

Elle a été conduite sur 6 lots de 14 porcs charcutiers ( 7 mâles castrés, 7 femelles) de 27 à $103 \mathrm{~kg}$ vifs, nourris individuellement en semi ad libitum jusqu'à un plafond de $2,4 \mathrm{~kg} / \mathrm{porc} / \mathrm{jour}$.

A un régime témoin "maïs + tourteau de soja cuit " à $I 7,9$ p. roo de matières azotées brutes $(\mathrm{MAB})$ et $0,93 \mathrm{p}$. Ioo de lysine sont comparés des régimes avec :

- substitution partielle ou totale du tourteau de soja par la farine de poisson à un niveau de lysine élevé (o,93 p. Ioo) environ);

- substitution partielle đu tourteau de soja par du tourteau de tournesol, du tourteau d'arachide ou un mélange des trois sources azotées précitées à niveau de lysine moindre (0,75 p. Ioo environ).

Les performances d'élevage et les résultats de découpe sont très voisins, quel que soit le type de complémentation utilisé.

Dans ces régimes très énergétiques ( $35^{\circ}$ kcal environ) à base de maïs comme seule céréale le niveau faible de lysine $(0,75$ p. Ioo) est insuffisant, surtout en début de croissance.

\section{2e Expérience}

Dans les mêmes conditions d'alimentation 6 régimes sont testés sur des lots de I 6 porcs en loges individuelles.

Le maïs est associé à deux sources azotées : le tourteau de soja " 50 " et les levures cultivées sur alcanes (levures "G », procédé BP Grangemouth).

Pour chacune de ces associations les niveaux de lysine et de MAB de l'expérience précédente ont été retenus et comparés à une ration à teneur en MAB plus faible ( 6 p. Ioo), mais à niveau de lysine élevé (o,93 p. roo).

Les performances d'élevage ont été modifiées favorablement par :

- la source azotée utilisée (levures " $G$ »).

- le taux de lysine élevé $(0,93$ p. Ioo) quand le niveau azoté est respectivement de : I 8 p. Ioo et de 16 p. Ioo. (Pour ce dernier niveau seulement dans le cas de l'utilisation du tourteau de soja " $50 "$ ). 


\title{
SUMMARY
}

TOTAL, OR PAR'TIAL, SUBSTITUTION OF COOKED SOYBEAN OIL-MEAL IN MAIZE DIETS

\section{Experiment 1}

The first experiment was carried out with 6 groups of I4 pigs ( 7 castrated males, 7 females) from 27 to $103 \mathrm{~kg}$ live weight, fed individually according to the semi ad libitum method till a maximum feed restriction level of $2.4 \mathrm{~kg} / \mathrm{pig} /$ day.

A control diet containing maize and cooked soybean oil-meal with 17.9 p. Ioo crude protein (CP) and 0.93 p. roo lysine was compared to diets with :

- partial or total substitution of soybean oil-meal by fish meal at a high lysine level (about 0.93 p. 10o);

- partial substitution" of soybean oil-meal by sunflower oil-meal, peanut oil-meal or a mixture of the three above mentioned protein sources at a lower lysin level (about 0.75 p. roo).

The performances and carcass dressing results were very similar whatever the type of supplementation used.

In these high energy diets (about $335^{\circ} \mathrm{kcal}$ - with maize as only cereal), the low lysine level (o.75 p. IOo) was insufficient, especially at the beginning of the growing period.

\section{Experiment 2}

In the same feeding conditions, 6 diets were tested on groups of 16 pigs each, penned individually.

Maize was combined with two protein sources, $i$. e. soybean " 50 " oil-meal and alcane yeast ("G " yeast BP Grangemouth method).

In each combination, the levels of lysine and crude protein of the previous experiment were used and compared with a diet with a lower CP content (I 6 p. IOo) and a high lysine content (o.93 p. I00).

The performances were favourably changed by :

- the protein source used ("G " yeast),

- the high lysine level (0.93 p. Ioo) when the protein level was I 8 p. roo and I 6 p. Ioo respectively. (The latter level was only used in the case of soybean " 50 " oil-meal.)

\section{LA DISTRIBUTION BI-HEBDOMADAIRE IE L'APPORT AZOTÉ PERMETTRAIT-ELLE L'OBTENTION DE CARCASSES MAIGHES CHEZ LES FEMELLES A L'ENGRAIS?}

\author{
G. CHARLET-LERY, B, DESMOULIN * et M.-T. MOREL
}

Laboratoire de Recherches sur la Conservation et l'Efficacité des Aliments,

* Station de Recherches sur l'Élevage des Porcs

Centre national de Recherches zootechniques, I. N. R. A., 78350 Jouy en Josas

\section{RESUMÉ}

La dissociation partielle des apports énergétiques et azotés au cours de la semaine (I I repas à taux azoté bas $B N$ et 2 repas à taux azoté haut $H N$ représentant 40 p. Ioo des apports protéiques), a été expérimentée chez les femelles en croissance après l'avoir été chez les mâles castrés. 